Bryn Mawr College

Scholarship, Research, and Creative Work at Bryn Mawr College

2014

\title{
Shifting Gears: Industrial Policy and Automotive Industry after the 2008 Financial Crisis
}

Seung-Youn Oh

Bryn Mawr College, soh03@brynmawr.edu

Let us know how access to this document benefits you.

Follow this and additional works at: http://repository.brynmawr.edu/polisci_pubs

Part of the Political Science Commons

\section{Custom Citation}

Oh, Seung-Youn, "Shifting gears: industrial policy and automotive industry after the 2008 financial crisis," Business and Politics 16.4 (2014): 641-665.

This paper is posted at Scholarship, Research, and Creative Work at Bryn Mawr College. http://repository.brynmawr.edu/polisci_pubs/28

For more information, please contact repository@brynmawr.edu. 


\title{
Seung-Youn Oh*
}

\section{Shifting gears: industrial policy and automotive industry after the 2008 financial crisis}

\begin{abstract}
Apart from being one of the hardest hit sectors during the 2008 financial crisis, the auto sector is also a prominent sector where emerging auto markets such as China have fared relatively well compared to their competitors in North America and Europe. This paper examines various ways that nations have shifted their policy gears to revive and restructure the automotive industry by using the case studies of the USA, France, and China. New sets of policy initiatives are contingent on particular industrial and institutional contexts, but both developed and developing countries have employed wide range of "murky" protectionist measures. This makes it unlikely for the WTO member countries to take a naming and shaming approach and file a case at the WTO level, which poses challenges to the WTO rules and trade liberalization.
\end{abstract}

\section{Introduction}

The 2008 global financial crisis greatly impacted the major automotive manufacturing countries with an unprecedented scale of market crash, rendering the automotive sector the hardest hit along with the banking sector. With the need to maintain employment and build industrial capacity, major automotive manufacturing countries intervened in the market through bailouts and subsidies for both producers and consumers at an unprecedented scale; this was politically unthinkable just a few years ago, especially in Europe and North America. The mercantilist sentiment of "exporting as good and importing as bad" arose, and "beggar-thy-neighbor" policies of discriminating against foreign imports and demanding repatriation of manufacturing base in exchange for state aid were widely adopted and justified as a way to fix market failures.

\footnotetext{
*Corresponding author: Seung-Youn Oh, Assistant Professor of Political Science, Bryn Mawr College, Dalton Hall 100 G, 101 N. Merion Avenue, Bryn Mawr, PA 19010, USA, e-mail:soh03@brynmawr.edu
} 
Such a simple equation, however, rests on the illusion that the automotive market crash is a temporary problem that can be rescued through bailing out domestic companies and blocking foreign brands. Instead, the crisis of the past decade has unearthed several long-term and deeply rooted structural problems of the automotive industry, especially those in developed economies. From the supply side, automotive manufacturers have suffered from excess production capacity since the early 2000s, followed by declining relative productivity and diminishing returns from innovation. From the demand side, the falling sales reflect structural market situations such as a high level of car ownership and demography in developed economies compared to that in the emerging economies. The 2008 credit crunch brought these problems to the surface by breaking the model of pumping up sales through easy consumer credit with zero-down payments and zero-interest financing.

This explains why the automotive industry is one prominent sector where emerging automotive markets such as China and Brazil have fared particularly well relative to their competitors. Their sales reflect new purchases rather than replacement, because their demographic structure and projections for income growth makes the crisis less of a structural problem and more of a temporary sales slump. Such a stark contrast between the economic woes of the liberal market economies and the relatively thriving economies in state-centric countries sparked a significant debate over newly strengthened industrial policies, while providing political justifications for mercantilist policies.

Domestic debates on the use of industrial policy involves whether government intervention is beneficial for the long-term competitiveness of the sector. Governments often lack omniscience on choosing winners and devising discernable exit strategies, and state intervention in a particular sector surrenders private business interest under political logic. ${ }^{1}$ What significantly concerns the proponents of trade liberalization is potential discrimination against foreign imports and even transplant companies within the same national boundary. Since governments are increasingly sensitive to populist calls to keep the manufacturing jobs at home, then it is worth having the debate whether foreign brands in America that hire American workers and source local parts should be viewed as domestic industries.

The employment of numerous forms of state intervention and outright domestic industry protections also raises important questions for the World Trade Organization (WTO). What implications will be faced by the WTO due to some of its "murky" protectionist measures that include bailouts, public procurement,

1 Barfield (2009); Brunel and Hufbauer (2009). 
and quantitative restrictions of import?2 Besides the nature of such measures, how are the WTO's trade prospects affected by its frequent use of discriminatory measures as its foremost method of surviving the financial crisis? Even if these measures are unwinding, would the WTO remain unscathed despite its former use of industrial policies?

This article examines the cumulative impact of diverse national policy measures to revive and restructure the automotive industry in response to the 2008 global financial crisis. In doing so, I first argue that the impact of state intervention varies depending on the compatibility between the condition of state aid and the source of the structural problems. The US government expedited necessary restructuring of the industry by tying state aid to job cuts and reductions in benefits, while the French government attempted to tackle massive overcapacity through freezes on factory closures and repatriation of some factories from other European countries. The French government has seemingly followed the costly precedent set by the British auto industry in the 1970s, where state intervention was utilized to keep domestic ownership, which postponed necessary restructuring and had a detrimental impact on saving jobs in the long-term. The development of a global production network also complicates the political payoff of protectionist and in-ward looking national strategies because of diverging interests between those who focus on volume maximizing (i.e., Fiat and Peugeot) mostly in regional market, and those who emphasize margins and aggressive expansion to emerging economies (i.e., Volkswagen). In Europe especially, the crisis has further divided the two and has certainly hurt the former.

Second, while trade restrictions have thus far played a small role relative to subsidizing domestic industry, national strategies in the form of taxing or restricting market access to foreign industries are more disputed at the WTO because of its clear negative cross-border spillovers, compared to the murky strategies of subsidizing domestic industries. The bailouts of domestic automakers against transplants are discriminatory; however, whether it is consistent with WTO rules depends on an impact that is not immediately measurable. In addition, the wide use of state intervention makes the mercantilist practice a new equilibrium and aggravates the collective action problem.

Third, three cases brought to the WTO in the automotive industry since 2005 suggest that the trade disputes often spiral into high-stake game of tit-for-tat and that the final ruling does not serve as a deterrent. Member states can still find a

2 Baldwin and Evenett define murky protectionism as "abuses of legitimate discretion which are used to discriminate against foreign goods, companies, workers, and investors” (Baldwin and Evenett 2009: p. 4). 
way to uphold its industry through various measures or spill over the tensions into different issue areas. Also, emerging economies, such as China, liberally implement industrial policies in order to achieve economic development goals and remove them only after coming into dispute at the WTO. Given the low prospect of the WTO in proceeding with trade liberalization, bilateral negotiations over free trade agreements have been gained currency. Most policymakers in developed countries have learned their lesson from the haunting memory of the 1930s when tariff protectionism prolonged and deepened the Great Depression. However, FTA negotiations are also hampered by narrowly defined sectoral emphasis and the mercantilist belief that imports are the problems of economic crisis.

This article begins by providing a broad overview of the global automotive industry and examples of key countries that exemplify the types of state intervention in the automotive sector in response to the financial crisis. The US case demonstrates how government intervention in the automotive sector effectively functioned as an emergency remedy in expediting the restructuring process. French governmental intervention in the sector is a classic example of how protectionism interferes with the national automaker's long-term competitiveness at the domestic and global level. Chinese policies serve as a representative case of the auto sector in emerging economies where the financial crisis is more of a sales slump problem rather than a structural issue. The final section discusses three WTO trade disputes in the automotive sector and evaluates the prospects of the WTO in forging trade liberalization in the wake of the 2008 global financial crisis.

\section{Overview of the global automotive industry}

During the 2008 financial crisis, nearly all sectors experienced decreasing sales as well as firms teetering on the edge of or falling into bankruptcy. Yet, in major car producing countries, the automotive sector was among one of the hardest hit by the crisis, accentuating the problem of excess production capacity from the pre-crisis era. It was also a prominent sector where emerging markets fared particularly well relative to their competitors. Within a span of 1 year, from late 2008 through 2009, global vehicle production dropped more than 10 million units in 2009, from the 72 million units that were built in 2007 (Figure 1). North America and Western Europe suffered a sharp drop in vehicle production and growth, making the annual growth rate of production from 2007 to 2008 decline by $17.5 \%$ for the US, 20.5\% for Canada, and 28.7\% for France (Table 1). On the other hand, emerging economies like Brazil and China reported positive growth, with Brazil increasing by $8.5 \%$, and China rising by $5 \%$. 


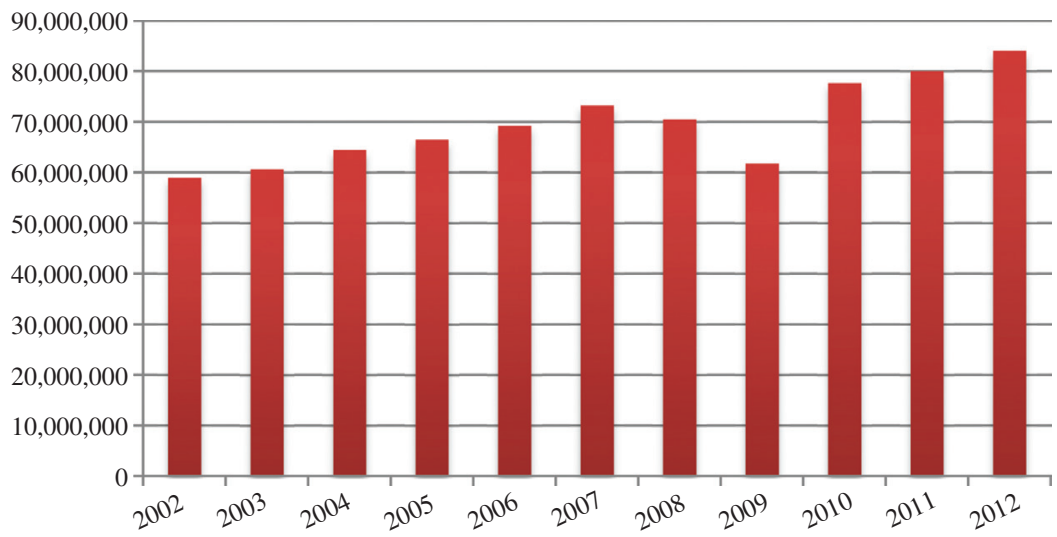

\begin{tabular}{|l|l|l|l|l|l|l|l|l|l|l|l|}
\hline Year & 2002 & 2003 & 2004 & 2005 & 2006 & 2007 & 2008 & 2009 & 2010 & 2011 & 2012 \\
\hline Unit (mil.) & 58.9 & 60.6 & 64.5 & 66.5 & 69.2 & 73.2 & 70.5 & 61.8 & 77.7 & 80 & 84.1 \\
\hline Growth rate (\%) & & 2.8 & 6.3 & 3.1 & 4.1 & 5.8 & -3.7 & -12.4 & 25.9 & 3.2 & 5.1 \\
\hline
\end{tabular}

Figure 1 Global auto production. ${ }^{3}$

Table 1 Passenger vehicle production levels and growth (2002-2008) ${ }^{4}$ [unit: thousands].

\begin{tabular}{|c|c|c|c|c|c|}
\hline & \multicolumn{3}{|r|}{ Annual growth } & \multicolumn{2}{|r|}{ Annual growth } \\
\hline & 2002 & 2007 & 2002-2007 (\%) & 2008 & $2007-2008$ (\%) \\
\hline \multicolumn{6}{|l|}{ North America } \\
\hline US & 12,280 & 10,611 & -2.88 & 8746 & -17.58 \\
\hline Canada & 2629 & 2602 & -0.21 & 2068 & -20.52 \\
\hline Mexico & 1805 & 2254 & 4.54 & 2154 & -4.44 \\
\hline \multicolumn{6}{|l|}{ Western Europe } \\
\hline France & 3292 & 3010 & -1.78 & 2145 & -28.74 \\
\hline Germany & 5145 & 6200 & 3.80 & 5500 & -11.29 \\
\hline Italy & 1427 & 1284 & -2.09 & 1085 & -15.47 \\
\hline UK & 1821 & 1770 & -0.57 & 1450 & -18.08 \\
\hline \multicolumn{6}{|l|}{ Northeast Asia } \\
\hline Japan & 10,258 & 11,596 & 2.48 & 11,564 & -0.28 \\
\hline South Korea & 3148 & 4085 & 5.35 & 3830 & -6.24 \\
\hline \multicolumn{6}{|c|}{ Emerging economies } \\
\hline Brazil & 1793 & 2960 & 10.55 & 3210 & 8.45 \\
\hline Russia & 1220 & 1654 & 6.28 & 1776 & 7.40 \\
\hline China & 3251 & 8890 & 22.29 & 9.340 & 5.06 \\
\hline India & 892 & 2046 & 18.06 & 2022 & -1.20 \\
\hline
\end{tabular}

3 Compiled from OICA, International Organization of Motor Vehicle Manufacturers.

4 Compiled from OICA, International Organization of Motor Vehicle Manufacturers. 
The blatant contrast between the economic woes in America and Europe and the relatively thriving performance in emerging economies reflect two major trends in the automotive sector that have developed over the past decade. Firstly, the past decade witnessed a rapid growth in terms of the global supply chain and overall outsourcing of manufacturing industries. ${ }^{5}$ Developing countries' shares in world-manufactured exports rose from 20\% in 1992 to $29 \%$ in 2000, and reached $39 \%$ in $2009 .{ }^{6}$ In 2010, non-OECD countries generated half of the world GDP measured in purchasing power parity, ${ }^{7}$ and for the first time, developing economies absorbed close to half of foreign direct investment inflows. ${ }^{8}$ Very few sectors besides the auto sector reflect such a shift of the center of gravity in demand and supply from developed to developing countries, especially to Asia and Eastern Europe. In terms of supply, market saturation in developed countries, high shipping costs, and trade barriers to access emerging markets prompted automakers from North America and Europe to increasingly relocate their production to emerging markets since 2000, as well as adopt "make-your-car-where-you-sell" strategies. Modular production and development of technology further accelerated the globalization of the auto production process. The center of demand has shifted as well. The automobile world market grew steadily by 3.5\% from 2000 to 2007 (Table 1); however, the share held by the US and Japan in global production fell from $40 \%$ to $30 \%$, while the share of non-OECD areas increased from producing one car in ten to one car in five. ${ }^{9}$ The economic crisis further reinforced and accelerated this trend as car sales and demands were maintained in emerging economies.

Secondly, selling autos through easy consumer credit has become a widely used business strategy for the past decade. By nature, auto sales are extremely responsive to economic cycles of boom and bust since purchasing a vehicle reflects discretionary spending. From the early 2000s, auto markets in North America and Europe have slowed down due to excess production capacity. ${ }^{10}$ Easy consumer credit with zero-down payments and zero-interest financing enabled automakers to pump up sales with large rebates. However, the 2008 credit crunch broke that model by decreasing access to affordable credit, therefore making many households postpone their car purchases. A sharp reduction in domestic vehicle sales along with a crash in key automotive export markets left every single

\footnotetext{
5 Gereffi, Humphrey, and Sturgeon (2005); Pilat, Cimper, and Webb (2008).

6 UNIDO (2011).

7 OECD (2013).

8 UNCTAD (2012).

$9 \operatorname{OECD}(2010)$.

10 Time, 30 July 2012.
} 
manufacturer suffering from significant cash burn. On the other hand, the emerging economies who were less integrated into the global financial system were partly unscathed by the credit crunch. They did not significantly participate in advanced financial services transactions such as subprime loans in the US. ${ }^{11}$ For example, $80 \%$ of vehicle purchases are credit-based in the US and the UK, and $75 \%$ in India. However, the opposite is true in China, where $80 \%$ of car purchases are made in cash. ${ }^{12}$ Undoubtedly, no auto market was immune to the impact of the financial crisis, but these two trends partly explain the varying impact of the crisis in different parts of the world: for saturated market in developed economies, the crisis unearthed existing structural problems of overcapacity and market saturation, while in emerging economies, it meant a temporary sales slump.

\section{National responses and governmental measures}

Given the grave impact of the automotive industry on job maintenance and overall manufacturing performance, both developed and developing countries have taken a variety of supporting measures to revamp their automotive sectors. Only in the banking sector did the government intervene on a larger scale than it did in the automotive industry. A range of factors motivated and justified governmental intervention in the automotive industry in the wake of the crisis. Firstly, geographically concentrated employment and strong labor unions make the industry politically sensitive, prompting governments to respond with various policies to boost car sales and directly support the industry. Secondly, the automotive industry's long supply chain with upstream and downstream industries has a significant multiplier effect on broader economic performance. Thirdly, because the automotive industry is extremely concentrated at the top, with a few large leading firms and hierarchical supply chains, political intervention seems to be feasible and manageable by propping up leading firms. Fourthly, bailing out automakers can help solve credit problems in cases where automakers have financing companies. Lastly, stimulating automotive demand is regarded as an effective way to strengthen aggregate demand by moving purchases forward..$^{13}$ Thus, governments in major automotive producing countries have adopted measures ranging from tax relief or subsidies to direct involvement in industry restructuring plans. Although these measures have been criticized as not only impeding structural

11 James (2008).

$12 \operatorname{IMVP}$ (2009: p. 4); PWC (2009).

13 In most countries, the bulk of vehicle sales are financed ( $90 \%$ in the US). 
changes that the industry needs to take in the coming years, but also functioning as potential protectionist measures against foreign commercial interest, ${ }^{14}$ pundits and experts agree on their necessary role in keeping the industry afloat.

- Credit warranties: This is the least controversial form of intervention and is typically not limited to the automotive industry. Most countries have initiated schemes to guarantee or extend credit. The most commonly used approaches to support the automotive industry are earmarking loans for research and development, developing environmentally friendly vehicles, or securing loans with company lands or buildings.

- Subsidized credit facilities: The slowdown of automotive markets in North America and in Western Europe was closely tied to the drying up of cheap consumer credit. For example, the total amount of cars being sold in the US market was significantly tied up with the credit of home equity lines, with $24 \%$ of total sales in 2006 being financed this way. When the availability of these loans dried up due to the 2008 mortgage crisis, sales of vehicles declined drastically: they dropped from over fifteen million in 2006 to just above ten million in $2009 .{ }^{15}$ Thus, various governments decided to provide subsidies to credit units of automakers.

- Purchase subsidies for consumers (Scrapping schemes): Besides producer subsidies, consumer incentives were also introduced to artificially uphold consumer demand. Governments subsidized the purchase of new vehicles to replace old energy-inefficient vehicles through the so-called "cash-for-clunkers" schemes. The main objective was to shift household expenditures from the future to the present and to introduce energy-efficient vehicles to yield environmental benefits. The conditionality of the program varied widely across countries. For example, the value of vouchers was $\$ 1300$ ( $€ 1000$ ) in France and $\$ 3300$ ( $€ 2500$ ) in Germany, creating a risk of distorted competition. As a result of these temporary measures that were set to expire by the end of 2009 in most countries, there was a boost in sales. In the US, the first half of 2009 observed a surge in sales, yet sales dropped back to their preincentive level with the end of incentive. Likewise, in Europe, new car registrations rose sharply since the beginning of 2009, with substantial increases in Germany, Austria, Italy, Portugal, the Slovak Republic and the UK. On the other hand, the French government did not consider the program to be successful since people swapped their old cars for cheap new cars manufactured outside Europe, rather than purchasing domestic brands. The nature of the program also varied from protectionist to non-discriminatory. Notably, the

$14 \operatorname{OECD}(2010)$.

15 Bai (2012: p. 16). 
German program was designed to avoid discrimination against foreign firms by bringing positive spillover effects to other countries that exported small and inexpensive cars to Germany, including the Slovak Republic, France and Italy. Germany's program also boosted car and parts manufacturing in Poland, which itself did not introduce any scrapping program. On the other hand, China's scrapping program was discriminatory and protectionist because it was used to encourage the purchase of local Chinese brands such as Geely and BYD.

- Direct governmental loans, loan guarantees or subsidies: Support has also taken the form of direct governmental loans and subsidies for firms facing difficulties. The direct insertion of working capital to specific companies is unlikely to come without policymakers gaining some level of influence over decision-making. This can be seen through the involvement of the US (and Canadian) governments in the quick bankruptcy procedures of General Motors and Chrysler that were characterized by exchanging large equity stakes for debtor-in-possession financing. Government intervention in strategic decision-making became more explicit by beginning to include conditions such as appointing new top management, demanding larger wage cuts, restructuring product portfolios, and insisting on additional plant closures. Several countries utilize this scheme as a stay-home bonus to maintain employment and domestic manufacturing. ${ }^{16}$

According to the Global Trade Alert database, a total of 57 state measures have been recorded in the automotive sector from July 2009 to February 2014; 42 measures have been implemented, and the rest have been announced and are pending implementation. Of the implemented measures, about 45\% (19 measures) are marked red, indicating a certain level of discrimination against foreign commercial interests. The most representative types in this category are state aids, bailouts and other forms of financial assistance to companies; every single country in the database has employed this measure (Figure 2). A total of 11 measures are flagged amber to denote potential discrimination against foreign commercial interests including import bans and local content requirements. Brazil has employed the most number of measures (16 measures) with seven green and five red measures, whereas all three of China's measures are flagged red with clear discrimination against foreign commercial interest.

Notably, most auto producing countries adopted bailouts, but there was no direct case that was brought to the WTO. The most distinct case was China's imposition of anti-subsidy tariffs on American-imported vehicles from GM and

16 The Telegraph, 24 October 2012. 

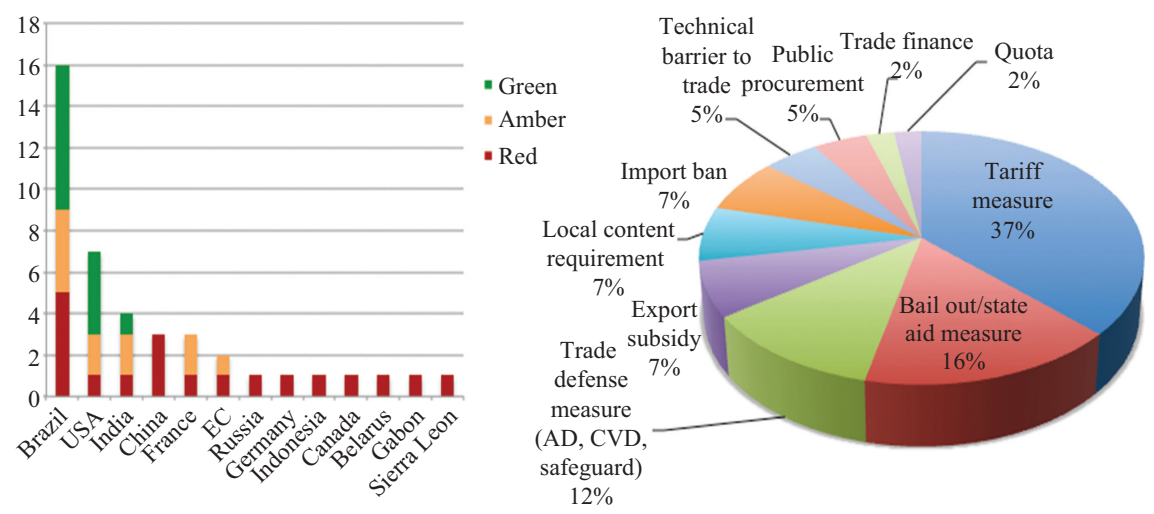

Figure 2 Implemented state measures in the automotive industry from global trade alert (July 2009-February 2014) ${ }^{17}$ [Total 42 measures].

Chrysler, arguing that the US government bailout had the effect of providing subsidies for these manufacturers' exports. However, given the wide use of sectoral intervention, there barely is a legitimate reason for member states to challenge other nations' subsidy programs by bringing a case to the WTO and take a naming and shaming approach. For example, France's then president, Nicholas Sarkozy, stated "the situation in Europe means that you cannot accuse any country of being protectionist when the Americans put up $\$ 30$ billion to support their automotive industry." ${ }^{\prime 18}$ This surely aggravates the collective action problem where each WTO member country is increasingly tempted to shirk their commitments and take opportunistic behaviors, thereby undermining the WTO norms and rules. ${ }^{19}$

\subsection{North America and the United States}

Although the automotive crisis was a global phenomenon, American manufacturers were relatively more affected than any of the other foreign manufacturers, driving the Big Three - GM, Ford, and Chrysler - to the verge of bankruptcy in 2008 and jeopardizing overall national economic performance. The Big Three suffered from the unprecedented speed and severity of the collapse of sales: GM suffered from a $45 \%$ drop in sales, Ford experienced a $42 \%$ decline, and Chrysler

17 Compiled from Global Trade Alert.

18 Baldwin and Evenett (2009: p. 5).

19 Olson (1965). 
underwent a 46\% decrease in the first four months of 2009 compared with the same period in 2008. The factors responsible for the severe drop in car sales have both micro and macro dimensions. The macro-level factor is the overall deep recession and the associated "credit crunch." In 2007, nearly two million new US cars were purchased with funds from home equity loans, ${ }^{20}$ and in mid-2008, the lack of access to automotive loans on affordable terms prompted buyers to postpone purchases. The instability of the job market combined with individual consumer finances discouraged consumers with working vehicles from taking on new loans and payments. Micro-level contributions include the recent overselling of cars due to cheap credit, price discounting, and the postponable nature of automobile purchases. This overselling has made the current distress even deeper than it otherwise would have been.

The US government took unprecedented steps to stave off complete collapse, including liquidation of any of the Big Three, and was thoroughly involved in both the adjustment and the substance of restructuring the automotive sector. The cost of the US governmental assistance to the automotive sector amounted to a total of $\$ 36.5$ billion. First, the federal government created the Automotive Industry Financing Program in December 2008 to provide $\$ 23$ billion of direct assistance to GM and Chrysler, under the conditions of acceptable restructuring plans by March 30, 2009, including union concessions, management changes, and product realignments. When Chrysler failed to abide by these conditions, it was forced into bankruptcy. Second, the crisis in the credit markets jeopardized the ability of these lenders to continue supporting sales. The government provided further assistance in the amount of $\$ 7.4$ billion to General Motors Acceptance Corporation ( $\$ 6$ billion) and Chrysler Financial ( $\$ 1.4$ billion), the financing arms of the two companies. Third, as a way to prevent spillover effects from the financial difficulties of GM and Chrysler onto their suppliers, the Supplier Support Program, which totaled $\$ 5$ billion in government financing, provided assistance to first tier suppliers designated by GM and Chrysler. Fourth, a Warranty Commitment Program of $\$ 1.1$ billion was set up to guarantee warranties on vehicles purchased during restructuring and to boost consumer confidence in the value of product warranties in the event of company bankruptcy. Lastly, the American Recovery and Reinvestment Act of 2009 established an office to coordinate assistance to communities and workers adversely affected by the loss of automotive manufacturing jobs.

Through restructuring, GM has emerged as a new firm. In exchange for about $\$ 50$ billion in investments, GM was forced to cut executive pay and eliminate 47,000 jobs in 2009; it also discontinued many of its brands such as Pontiac,

20 Bai (2012). 
Cadillac, Chevrolet and GMC. Chrysler is now owned by the United Auto Workers union (55\%), as well as by Fiat S.P.A. (35\%). ${ }^{21}$ Ford was the only company to survive without entering into bankruptcy; this was mainly because it received a huge line of credit in 2007. As of early 2014, all the major American manufacturers have gone on to increase their sales and have recently posted profits regarding their sales figures.

In that case, what would be the broader implications of such sectoral intervention? While not alone in bailing out its automotive industry, the US' action affects international rules and practices for sectoral intervention. First, the bailouts for GM and Chrysler cannot escape the critique of discriminating against foreign automakers who not only produce vehicles in America, but are also important for domestic employment and the overall health of manufacturing. In 2009, the House of Representatives approved a provision to exclusively use Big Three models for government procurement; however, Congress rejected it because it was more protectionist and discriminatory than other Buy American Provisions by excluding vehicles made in the US by transplant factories of foreign automakers. ${ }^{22}$ Second, as companies around the world accept government bailouts, they too are being forced to march to the priorities set by political leaders. Since GM struggled in the US market, half of its profits came from emerging markets such as China. In May 2009, GM informed Congress of its plan to produce roughly 50,000 subcompacts in China annually to be sold in the US market. However, as part of its deal with the UAW, GM agreed to not import cars from China, but produce them in the US instead. It is debatable whether this can be interpreted as a government-mandated quantitative restriction on auto imports or merely part of a labor deal with the UAW.

\subsection{Western Europe and France}

As the engine of the European economy, the European automotive industry generates a turnover of $€ 551$ billion, representing around $6.5 \%$ of Europe’s GDP, and creating about one in ten jobs, directly or indirectly. ${ }^{23}$ The slump in the European automotive market began before the start of 2008 financial crisis with production

21 The Wall Street Journal, 28 April 2009.

22 According to the Section 504 of the "Energy and Water Development and Related Agencies Appropriations Act, 2010," "None of the funds made available in this Act may be used to purchase passenger motor vehicles other than those manufactured by Ford, General Motors, or Chrysler." For the details, please see Global Trade Alert (http://www.globaltradealert.org/node/312).

23 ILO (2010): according to the report, the industry directly and indirectly provides jobs to over 12 million families. The multiplier effect of the 2.2 million direct employees at vehicle manufacturers and their suppliers is enormous. One job at the vehicle manufacturer creates four more at suppliers and another five in related sectors and retail. 
capacity being about 30\% greater than the market capacity. ${ }^{24}$ Although automakers were able to pump up sales with large rebates and easy consumer credit, sales remained within a relatively narrow trading range of about 17 million units. The crisis broke that model, leading to devastating effects on European automakers, along with serious implications for the wider economy. In December 2008, the registration of new cars fell to 19\% in the European Union, 62\% in Ireland, 50\% in Spain, 46\% in Denmark, 45\% in Sweden, 21\% in England, 16\% in France, and $7 \%$ in Germany. ${ }^{25}$

At the European level, the only significant measure to deal with the crisis was the European Investment Bank's loans to manufacturers and suppliers of up to $€ 8.5$ billion in 2009. The European Commission adopted the Temporary Framework in order to grant member states permission to grant financial aid to companies. The European Union originally maintained strict state aid programs under close monitoring by the European Commission that had the threat of tough disciplinary action. However, the European Commission had to compromise when it found itself being marginalized by the member states that insisted on offering bailouts and financial aid to domestic companies.

At the national level, the interventions by EU member states were predominantly bailouts, which was politically unthinkable just a few years ago. ${ }^{26}$ However, a lack of coordination between states led to an uneven playing field among automakers by producing a risk for distorted competition depending on location. Thus, the impact of state intervention varied because European car manufacturing clearly splits into two camps - one is dominated by firms such as Volvo, Jaguar and Land Rover, who chose the strategy of maximizing margins and aggressively expanding to emerging economies in China or India. ${ }^{27}$ The others are those who focus on maximizing volume and emphasize European markets such as Peugeot, Fiat and Renault. The crisis has further divided the two, and the market has ruthlessly hurt the latter. The most affected markets were France, Spain and Italy, where almost $85 \%$ of the cars sold are small and medium-sized models that already have lower margins and European markets.

The French governmental intervention exemplifies the dilemma facing the automotive industry in continental Europe - i.e., how to tackle massive overcapacity with freezes on job cuts and factory closures. France is home to two of the world's top ten automakers by volume. Peugeot ranks second among European

24 Time, 30 July 2012.

25 Brunel and Hufbauer (2009: p. 5).

26 Italian government provided a $\$ 1.7$ billion package to stimulate car sales; the British government provided a $\$ 3.25$ billion lifeline for the sector. Forbes, 9 February 2009.

27 Ford sold Jaguar and Land Rover to Ta ta in 2008 while Geely Automobile purchased Volvo. 
automakers after Volkswagen, and Renault is another French champion whose largest shareholder is the French government, which holds 15\% ownership. Both have severely suffered as a result of their heavy reliance on relatively lowmargin models in the declining European car market. As an initial aid package, the government provided a total of $€ 1.3$ billion bailout funds, $€ 300$ million for scrapping schemes, and $€ 1.0$ billion euros ( $\$ 1.92$ billion) of preferential rate loans to the financing arms of the carmakers on December 2008. The French government utilized generous industrial policies to ensure that domestic companies remained loyal to the French market. In February 2009, the government offered bailouts of $€ 3$ billion ( $\$ 3.9$ billion) for the duration of 5 years, an interest rate of $6 \%$ to both Peugeot and Renault. ${ }^{28}$ The loans were conditional on refraining from any major restructuring plans: halting layoffs, freezing moving production abroad, and suspending factory closures in France for the duration of bailouts. ${ }^{29}$ As a result, in 2010, Renault was forced to drop its plan of outsourcing the production of its subcompact car (the Clio) to Turkey. The construction of a Peugeot plant in the Czech Republic also upset then president, Sarkozy, who stated that building a plant in India to sell French cars to Indians was perfectly acceptable, but building a plant in the Czech Republic to sell cars in France was not. ${ }^{30}$ Such a measure intended to hurt the long-term competitiveness of the French automakers without adjusting other economic conditions like labor cost. ${ }^{31}$ Between 2000 and 2010, unit labor costs in the French automotive industry went up by $8 \%$, compared with only $1.6 \%$ in Germany making labor costs about 20\% higher in France than in Germany, far higher than in countries such as Romania, where Renault builds the Logan. In spite of governmental support (or arguably because of governmental support) the crisis further distressed automakers, forcing Peugeot to post a net loss of $€ 5$ billion in 2012. In response to Peugeot's subsequent plan of shutting down the Paris-region plants and laying off 8000 workers, the French government provided Peugeot's financial unit, Banque PSA Finance, with credit guarantees up to $€ 7$ billion. In addition, the François Hollande government added several conditions to influence company decisions by having the state and workers receive a seat on the board of directors, as well as setting up an outside committee with veto power over any significant changes in Peugeot's operations. ${ }^{32}$ The French industry minister, Arnaud Montebourg, emphasized that Peugeot

28 Forbes, 2 September 2009; Automotive News, 9 February 2009.

29 The Independent, 21 January 2009.

30 The Telegraph, 9 February 2009.

31 The Wall Street Journal, 19 March 2009.

32 Bloomberg, 24 October 2012; New York Times, 24 October 2012; Spiegel, 17 August 2012. 
represents "the history of France, a territory, a national idea" in his meeting with Peugeot officials. ${ }^{33}$

However, the mercantilist spirit and the "beggar-thy-neighbor" policy of repatriation of production from other EU member states delay the deep restructuring necessary to boost companies' global competitiveness. French automakers were unable to raise prices to keep up with cost increases because, unlike their German competitors such as Audi, BMW and Mercedes-Benz, they do not make any luxury cars. Initially, this meant declining profits, but now, French carmakers are actually losing money and missing out on the opportunities offered by globalization. Peugeot sells more than half of their cars in Europe, where the market is shrinking, whereas Volkswagen sells only about a third of its cars in Europe and is establishing a strong presence in emerging economies such as the Chinese market. Employees at Renault's plant in Romania are working overtime to keep up with demand for two low-cost models, while Renault is struggling to get by at its domestic base. ${ }^{34}$ The inward looking auto industrial policy may retard the recovery process of the sector even when the general economy recovers; this is especially true because the crisis in the automotive industry in Europe is not a temporary slump since the potential for increased sales are simply capped by demographics and meager projections for income growth. Under shrinking demand and rising costs, it is clear that future growth lies in overseas markets and that only the innovative car manufactures can survive.

\subsection{Emerging economies and China}

Emerging economies fared relatively well during the 2008 financial crisis partly due to a shift of the supply and demand of automobiles from developed to emerging economies and their relatively closed financial systems. This trend is well pronounced in the case of China. China overtook the US in total vehicle production with an output of 9.5 million vehicles in 2008 and Japan in 2009, to become the world's largest producer with a production of 13.6-million vehicles (Figure 3). China's annual vehicle output increased from $<2$ million vehicles in the late $1990 \mathrm{~s}$ to over 18 million in 2011, almost doubling its 2008 output. However, China is not

33 Spiegel, 17 August 2012.

34 They offered compensation packages to entice some 10,000 factory workers in France to leave their jobs. Both are relying heavily on "partial unemployment" schemes, under which employees work half-time and receive about $70 \%$ of their wages, which are subsidized by the state. 


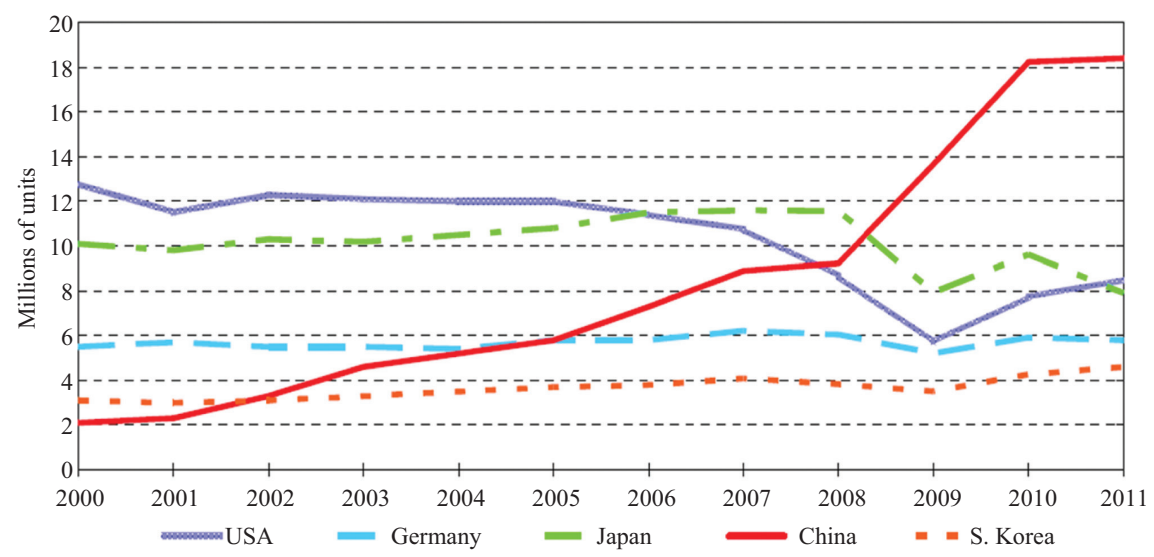

Figure 3 Automotive production by country (2000-2011)..$^{35}$

unscathed by the 2008 crisis - its auto sales growth of almost 9\% in January 2009 is still a sharp decline from its $24 \%$ increase in January $2008 .^{36}$

China's intervention in the automotive sector shows a somewhat different pattern from other industrial sectors where policies favor SOEs at the expense of foreign companies. China's government's strict ownership regulations on foreign investment produced bifurcated actors of 1) joint ventures (JVs) between Chinese state-owned enterprises (SOEs) and foreign automakers, as well as 2) Chinese independent automakers. Due to this bifurcated market structure, China's intervention in the sector is geared towards promoting domestic independent automakers, at the expense of JVs and SOEs. In response to the financial crisis, the Chinese government developed the following set of industrial policies for the automotive sector. First, the government forced the foreign partners of JVs to develop local brands, establish R\&D facilities, and add electric vehicles to their product lineups as a necessary condition to build new plants or expand capacity. ${ }^{37}$ According to an executive from Peugeot Citroen, a local brand was part of the deal in its new JV with Chang'an; Volkswagen also confirmed that it was considering developing local brands in order to fulfill the conditions of building a new plant in Foshan. ${ }^{38}$

In 2008, major JVs began announcing their plans to develop low-cost models for sale solely in China, such as Guangzhou Honda's Everus S1, which is just an older yet rebadged model of the Honda Fit. ${ }^{39}$ These indigenous brands are

35 Teng (2012).

36 Gasgoo Automotive News, 4 February 2009, "China May Cut Second-Hand Car Sales Tax to 1\%.”

37 Automotive News China, 24 April 2012.

38 Financial Times, 1 March 2011.

39 Motor Trend, 9 August 2011. 
created out of political conditions, not out of commercial calculation, so it is hard to predict their success in the market in the long run. Foreign manufacturers basically recycle their old products as a new JV sub-brand without allowing SOE partner to gain any technological advancement..$^{40}$ In addition, international parent companies do not fully support these models, as sub-brands are owned by the JVs and not by international parent companies.

Second, while pressuring JVs to develop indigenous models, the government has used stimulus packages and governmental procurement to promote Chinese independent automakers such as Chery and Geely. ${ }^{41}$ In November 2008, the Chinese government introduced a financial stimulus-spending package of four trillion RMB ( $\$ 586$ billion), as well as financial incentives to encourage vehicle ownership. As part of the package, the National Development and Reform Commission issued the Automotive Industry Readjustment and Revitalization Plan in March 2009. First, the Plan launched an 18-month cash-forclunker program, offering subsidies from 5000 to 18,000 RMB (\$735-\$2647), depending on vehicle category and engine size. It even reached rural areas, thereby encouraging farmers to trade in their old, environmentally unfriendly vehicles by providing a 10\% discount and a maximum subsidy of $5000 \mathrm{RBM}$ (\$735) per household. By the end of December 2009, the Chinese government had subsidized the purchase of 5.84 million cars for a total of 8.68 billion RMB (\$1.25 billion). ${ }^{42}$ Second, the Plan reduced the vehicle purchase tax from $10 \%$ to $5 \%$ on smaller passenger cars with engines of $1.6 \mathrm{~L}$ or less. The tax was then raised to $7.5 \%$ in 2010, and expired at the end of 2010. These two measures disproportionally favored independent automakers over JVs, since their main production focused on smaller and less expensive cars. The 2009 stimulus package not only increased the mini car market as a whole by $36 \%$, but also increased the market share of four independent automaker models (Cherry QQ, BYD FO, Geely Panda and Great Wall Peri) to 55\% within a month of announcing the tax breaks and subsidies. ${ }^{43}$

Third, the Plan adopted Buy China provisions for government procurement by requiring no $<50 \%$ of replacement vehicles of official governmental fleets to be bought from independent Chinese automakers. A Wall Street Journal report cited Xinhua, the Chinese official news agency, to show that the annual official

40 China Car Times, 12 January 2012.

41 Chery and Geely once reached $5.1 \%$ and $4 \%$ of the market share respectively in 2007, but suffered at $2.8 \%$ and $2.6 \%$ in 2012.

42 Teng (2012).

43 Chang (2011). 
vehicles procurement budget was more than 100 billion RMB (approximately $\$ 15.6$ billion) in 2011.44

In 2012, the Ministry of Industry and Information Technology released a draft of "The Model Directory for Selection of Vehicles for Use by Party and Government Organs 2012.”45 All 412 models approved for procurement by state agencies are limited to Chinese local brands by lowering the price limit from 250,000 RMB to $180,000 \mathrm{RMB}$, as well as added requirements to the R\&D spending and duration. ${ }^{46}$ Although this list would give Chinese automakers an advantage in a fleet market worth about 120 billion RMB (approximately \$19 billion), it is questionable whether such a policy would benefit domestic car manufacturers in the long run and make them more competitive. In response to the complaints from the EU Chamber in China on discriminating against JVs, ${ }^{47}$ Li Yizhong, a Chinese official at the Ministry of Industry and Information Technology, argues that the selection criteria falls in line with WTO regulations since it includes engines under $1.8 \mathrm{~L}$, and prices below 180,000 RMB. ${ }^{48}$

In addition to the discriminatory nature of such measures, ${ }^{49}$ foreign companies express worry that the door for fair competition in public procurement is tightly shut since China has not signed the WTO's Government Procurement Agreement. When China joined the WTO in 2001, it promised to join the Government Procurement Agreement. Currently, it defends its buy national program as being consistent with similar programs in other WTO countries such as the Buy American Act in the US. ${ }^{50}$ However, the Buy American Act requirements are waived where the US has trade agreements with signatories of the Government Procurement Agreement and countries that the US has signed free trade agreements with.

44 The Wall Street Journal, 26 November 2011; Bloomberg.com, 26 February 2012; China.org.cn, 1 March 2012; Automotive News China, 2 March 2012.

45 The Website of the Ministry of Industy and Information Techonology of the People's Republic of China, 24 February 2012.

46 Companies have to spend no less than three percent of annual revenue on R\&D in the last 2 years. The only exceptions to the policy are foreign-built and JV luxury vehicles bought for officials ranking at or above the vice-minister level including Audi, Mercedes Benz and BMW models. The announcement aims to help local brands gain in the market of government fleets of 80 billion RMB ( $\$ 12.7$ billion) at the expense of JVs and their foreign brands. The list includes Fir Auto Works' Hongqi, SAIC’s Rongwei and Mingjue, Tianjin Xiali to name a new.

47 The China Times, 27 February 2012.

48 Ajoo Kyungje, 9 March 2012.

49 European Union Trade Commission (2010).

50 Matechak and Gerson (2010). 


\section{Implications for trade liberalization}

The rise of mercantilist spirit and protectionist intervention measures in the automotive sector clouds the prospects of trade liberalization at the global level as national intervention becomes the new norm in the face of the unprecedented crash of the automotive market. National strategies which take the form of taxing or restricting market access to foreign industries are more disputed at the WTO because of its clearly negative cross-border spillovers, compared to inward looking strategies of subsidizing domestic industries. Bailouts of domestic automakers against transplants are discriminatory yet murky, and their impacts are not immediately measureable.

As several critical cases brought before the WTO demonstrate, trade disputes are politically waged as tit-for-tat game, and spiraling into different measures instead of serving as a deterrent. Since 2005, there have been three trade disputes in the automotive sector, all involving China and the US. The first case is China's Measures Affecting Imports of Automobile Parts (DS 340), by which the US, followed by the E.U. and Canada, contested China's tariffs on imported cars in 2006. The second case deals with China's subsidies for local automakers - Certain Measures Affecting the Automobile and Automobile-Parts Industries (DS 450) brought by the US in September 2012. The third and the most recently concluded dispute case is on China's anti-dumping and countervailing duties on certain automobiles from the US (DS 440).

China's WTO entry in 2001 reformulated the rule of the game in the automotive sector through its introduction of new tariff regulations and liberalization measures. China not only abandoned the local content requirement that had been employed for nearly two decades, but also lowered the tariff on imported cars from $80 \%$ to $100 \%$ to $25 \%$ and on imported parts and components from $15 \%$ to $50 \%$ to $10 \%$ by July 2006 . However, to counteract the removal of local content regulation, in 2004 the Chinese government adopted severe measures on imported automotive parts. If a final vehicle produced in China has more than $60 \%$ of imported parts in terms of value or number, it would be viewed as a completely imported car, and charged a $25 \%$ tariff instead of the $10 \%$ tariff on automotive parts. ${ }^{51}$ Foreign parts makers outside of China widely criticized such measures as market entry barriers and formed a strong export-lobbying group. They argued that the tariffs constitute a discriminatory charge that favor Chinese originating automotive parts and serve as a subsidy for automakers to use domestic rather than imported parts. ${ }^{52}$

51 General Administration of Customs Public Announcement of People's Republic of China, No. 4, which entered into force on 1 April 2005.

52 For the background of the dispute, USTR News, 18 July 2008. 
In 2006, pressured by domestic automotive parts makers, trade representatives from the US, the E.U. and Canada contested China's tariffs on imported automotive parts at the WTO. Beijing argued that the measures were necessary corrective actions. In other words, it claimed that they were put in place to prevent importers from circumventing higher taxes on finished cars through illicitly importing whole cars in split shipments of automotive parts. After 4 years of negotiations and WTO reviews, the Chinese government removed the measure in August 2009.

This ruling potentially benefits auto parts exporters globally by removing the measures against all imports. However, it has less impact than expected on the auto parts sourcing and imports for the global automakers operating in China. US auto parts exports to China increased from \$893 million in 2008 to \$937 million (4.9\%) in 2009, and again $36.4 \%$ to 1.3 billion in $2010 .{ }^{53}$ However, it is hard to say that the increase in 2010 is the direct result of the removal of import tariffs. The US auto parts trade deficit has been steadily increasing since 2001, except during 2009, since it was the year immediately after the financial crisis. While almost $80 \%$ of American parts exports went to Canada, Mexico, the E.U., and Japan in 2009 and 2010, the US had the greatest auto parts trade deficit with Japan. Luxury vehicles such as BMW, and those with engines of $2.5 \mathrm{~L}$ or more are mostly produced in foreign countries and exported to China. ${ }^{54}$

Furthermore, the development of global supply chains complicates the domestic political payoff in contesting Chinese measures at the WTO, and diverges interests between export-lobbying groups in home countries and localized suppliers in emerging markets. In his interview with The New York Times, Kevin Wale, the President of GM, commented that “China's decision to comply with the WTO rules on the tariffs on the imported automotive parts will have virtually no impact on our operation, because most of our operation is already localized and produced within China." 55 This shows how localized supply chains ensure that the automakers operating in China have been relatively less affected by the ruling. China's current top automaker Shanghai GM, started its JV in 1997 and achieved a localization rate of over $90 \%$ by the end of the 1990s. GM's localized suppliers are not directly benefiting from the enlarged market access, thereby making the market entry of independent auto parts suppliers abroad less concerning. Unlike the assumptions of existing literature on MNCs as the main drivers of liberalization,

53 The US-China auto parts trade deficit had grown six-fold from only \$1.5 billion in 2001 to almost $\$ 8.2$ billion in 2008. China's auto parts exports to the US alone have increased $43 \%$ from 2004 to 2009.

54 In 2011, the US exported about 92,000 luxury vehicles, worth about \$3 billion to the Chinese market.

55 The New York Times, 31 August 2009. 
MNCs often covertly support protectionist measures at sub-national levels to succeed in a competitive and fragmented market. ${ }^{56} \mathrm{JV}$ requirements especially created a distinctive pattern of encouraging intra-national competition between regional JVs rather than competition between foreign and domestic companies. In alliance with SOEs and their foreign partners, sub-national governments often thwart the liberalizing effects of international and national regulations in order to succeed in the Chinese market. In these interactions, MNCs are hardly the consistent champions of economic liberalization that they are often taken to be, but rather allies of sub-national actors who support local protectionism.

China's compliance with WTO rulings reflects Beijing's realpolitik and skillful navigation through the limitations of the WTO's dispute-resolution rather than socialization. China often liberally implements industrial policies in order to achieve its economic development goals; it only removes them after they come into dispute at the WTO through "convenient compliance." ${ }^{57}$ This in turn explains the weakness of the WTO final ruling that it does not serve as a deterrent. China's efforts to boost the automotive sector have not ended with resolving tariffs on imported automotive parts, continuously causing concern among foreign governments and major automotive MNCs. In September 2012, the US opened a new case against China at the WTO over China's March 2009 stimulus plan for domestic automakers - Certain Measures Affecting the Automobile and Automobile-Parts (DS 450). ${ }^{58}$ The stimulus plan for the automotive sector as illustrated in the earlier section includes lowering the sales tax on vehicles with small engines - which favored Chinese local brands - creating a $\$ 1.5$ billion fund to promote technical innovation, and offering subsidies for developing proprietary brands and building export bases for autos and auto parts..$^{59}$ Adopting new industrial policy measures to revitalize the auto sector despite the impact of removed tariffs on imported auto parts suggests the continuous nature of China's compliance, which eludes the WTO rule enforcement.

The most recently concluded case against China in May 2014 is regarding China's anti-dumping and countervailing duties on certain automobiles from the US brought by the US government in July 2012. ${ }^{60}$ This case shows how WTO trade disputes are used as high-stake game of tit for tat. China's Ministry of Commerce announced the initiation of such trade remedy shortly after the Obama

\footnotetext{
56 Oh (2013).

57 Oh (2014).

58 For the detail, please see World Trade Organization, Dispute Settlment: Dispute DS 450 China - Certain Measures Affecting the Automobile and Automobile-Parts Industries.

59 USTR (2009: p. 68).

60 USTR (2012).
} 
administration decided in September 2009 to impose a safeguard measure against Chinese tire imports. In December 2011, China began imposing antidumping duties range from $2.0 \%$ to $21.5 \%$, claiming that these vehicles were being sold at less than fair value (i.e., "dumped”) into the Chinese market. China also imposed additional anti-subsidy tariffs of $12.9 \%$ on large-engine passenger vehicles from GM and 6.2\% on Jeeps from Chrysler arguing that the US government bailout for GM and Chrysler had the effect of providing subsidies for these manufacturers' exports. In July 2012, the US brought the case to the WTO with the claim that China's "unjustified duties" affected about $\$ 5$ billion in automobile exports. ${ }^{61}$ In May 2014, after 22 months of dispute process, the WTO panel ruled against China on the ground that China had failed to prove that the imports were causing any injury to its domestic industry. International free-trade rules require a so-called injury determination to prevent countries from imposing tariffs to forestall imports from entering at all, instead of waiting to see if they actually cause a problem. However, losing a WTO case does not necessarily play a deterrent role as illustrated above.

Concluding comprehensive bilateral free trade agreements with Asian and emerging countries as a way to move forward with trade liberalization and gaining access to foreign markets could be an option. However, the mercantilist spirit of imports would have a bearing on negotiating parties, which further feeds the expectation that each country has to win in every sector. It is already well known in the literature that protectionists are more likely to mobilize and shape policy than the "winners" from liberalization, due to the concentrated and more immediate nature of the losses incurred and the greater diffusion of the benefits. ${ }^{62}$ The EU signed a landmark FTA with South Korea in 2011 but was temporarily blocked over fears of increased car imports and a veto by Italy. Thus, it is important to remember that the crisis was neither caused nor worsened by foreign imports. Also, in the case of Europe, believing that limiting imports will give European brands a chance to recover does not take into account the fact that the efficiently run European brands actually dominated other European countries and not the imports. Without recognizing the fundamental source of the problems, the auto market might not rebound even if the general economy does.

\section{Conclusion}

Following the financial crisis, policy and academic debates about the potential merits of industrial policy gained huge currency as governments urgently

61 The New York Times, 23 May 2014.

62 Baldwin (1985); Hillman (1989); Grossman and Helpman (1994); Hiscox (2002). 
searched for new ways to increase growth and employment. ${ }^{63}$ As one of the most severely affected sectors by the crisis, the automotive industry has been the center of government's defensive industrial policy of rescuing and restructuring. However, the rise of global production network and the growth of emerging economies as promising centers of production and demands for vehicles require new sets of policy initiatives contingent on particular industrial and institutional contexts.

The 2008 financial crisis provides a turning point of rethinking inwardlooking and domestic manufacturer focused industrial policies. The automotive market crash is neither a passing problem nor caused by foreign imports. Instead, the crisis of the past decade has unearthed deeply rooted structural problems. Policies that are mercantilist and protectionist would rather hamper the competitiveness of domestic automakers even after the industrial policies are unwinding. Britain already learned the lesson in the 1970s that domestic ownership and full employment in the automotive industry is not the very manifestation of national pride. Aggressive expansion to emerging markets and even attracting more transplants of foreign-owned automakers to home base can turn out to be more strategic and effective than repatriation or hampering imports. It is not surprising that automakers such as Volkswagen who focus on margins and aggressively expanding to new manufacturing bases in emerging economies have weathered through the crisis better than those who emphasize volume maximization with low margin in regional markets.

Setting aside the counterfactual claim that protectionism would have been worse during the crisis in the absence of WTO rules, states have deliberately attempted to circumvent existing multilateral trade rules. Concerning voices have been raised whether the automotive industry might follow the precedent of the agricultural sector of removing itself from the rules of the international trading system. ${ }^{64}$ Although the automotive sector would not exactly follow suit, the WTO's trade prospects are affected by member countries' frequent use of discriminatory measures as their foremost method of surviving the financial crisis. Since many countries either have thought about or are contemplating using murky protectionist tools, it may very well be that no WTO member will challenge another WTO member over protectionist measures. In the face of opposition from member countries, even the European Union had to make temporary acquiescence to relax rules for financial assistance to companies at the national level. Moreover, due to the failed Doha round for the past decade, economic and trade liberalization have proceeded with litigation and contentious interpretations of WTO rules.

63 Aggarwal and Evenett (2010, 2012); Rodrik (2010).

64 Brunel and Hufbauer (2009). 
However, cases that are brought to the WTO tend to be part of a big high-stakes game of tit-for-tat as seen in retaliatory series of trade tensions between the US and China. When emerging countries like China can game the WTO system and the WTO disputes are used as a tit-for-tat between China and the US, this raises important systemic issues that need to be investigated further for not only the WTO but also free market principles, more generally.

\section{References}

Aggarwal, Vinod K., and Simon J. Evenett. 2010. "Financial Crisis, 'New’ Industrial Policy, and the Bite of Multilateral Trade Rules.” Asian Economic Policy Review 5 (2): 221-244.

Aggarwal, Vinod K., and Simon J. Evenett. 2012. "Industrial Policy Choice During the Crisis Era." Oxford Review of Economic Policy 28 (2): 261-283.

Bai, Xue. 2012. "The Effects of the 2007-2009 Economic Crisis on Global Automobile Industry." Applied Economics Thesis at Department of Economics and Finance, State University of New York College at Buffalo.

Baldwin, Richard. 1985. The Political Economy of US Import Policy. Cambridge, MA: MIT Press.

Baldwin, Richard, and Simon J. Evenett. 2009. The Collapse of Global Trade, Murky Protectionist, and the Crisis: Recommendations for the G20. London: Centre for Economic Policy Research: http://www.ycsg.yale.edu/focus/papers/Protectionism.pdf.

Barfield, Claude. 2009. "Protectionism and the Global Economic Crisis.” American Enterprise Institute. Accessed 21 September 2014. http://www.aei.org/article/economics/fiscalpolicy/protectionism-and-the-global-economic-crisis/.

Brunel, Claire, and Gary C. Hufbauer. 2009. "Money for the Auto Industry: Consistent with WTO Rules." Peterson Institute for International Economics. Number PB09-4, February 2009. http://www.iie.com/publications/pb/pb09-4.pdf

Chang, Crystal. 2011. "Stumbling Toward Capitalism: The State, Global Production Networks, and the Unexpected Emergence of China's Independent Auto Industry.” Ph.D. diss., Berkeley: University of California.

European Union Trade Commission. 2010. Trade, Growth and World Affairs: Trade Policy as a Core Component of the EU's 2020 strategy. European Trade Commission. http://trade. ec.europa.eu/doclib/docs/2010/november/tradoc_146953.pdf.

Gereffi, G., J. Humphrey, and T. Sturgeon. 2005. "The Governance of Global Value Chains.” Review of International Political Economy 12 (1): 78-104.

Gene M. Grossman and E. Helpman. 1994. "Protection for Sale." The American Economic review 84 (4): 833-850. http://pages.uoregon.edu/bruceb/Andrea.pdf.

Hillman, A. 1989. The Political Economy of Protection. London: Harwood Academic Publisher.

Hiscox, M. 2002. International Trade and Political Conflict. Princeton, NJ: Princeton University Press.

ILO. 2010. “Automotive Industry: Trends and Reflections.” The Global Economic Crisis Sectoral Coverage. Working Paper 278. International Labor Organization.

IMVP. 2009. "The Global Automotive Industry Crisis: A Way Ahead.” An IMVP Position Paper. Cambridge, Massachusetts: IMVP, MIT. 
James, William E. 2008. "The US Financial Crisis, Global Financial Turmoil, and Developing Asia: Is the Era of high Growth at an End?” ADB Economics Working Paper Series. Mandaluyong City, Philippines: Asian Development Bank.

Matechak, Jason, and Brett Gerson. 2010. “Can China’s Government Procurement Market Be Cracked?” China Business Review 37 (3): 34.

OECD. 2010. "The Automobile Industry in and Beyond The Crisis." Economics Department Working Paper No. 745. Paris: Organization for Economic Cooperation and Development.

Oh, Seung-Youn. 2013. "Fragmented Liberalization in the Chinese Automotive Industry: The Political Logic behind Beijing Hyundai's Success in the Chinese Market.” China Quarterly 216: 920-945.

Oh, Seung-Youn. 2014. "Gone with the Wind: How China Outsmarts the WTO Rulings in the Wind Industry."Asian Survey (In Press).

Olson, M. 1965. The Logic of Collective Action: Public Goods and the Theory of Groups. Cambridge, MA: Havard University Press.

Pilat, D., A. Cimper, K. Olsen, and C. Webb. 2008. "The Changing Nature of Manufacturing in OECD Economies." In Staying Competitive in the Global Economy: Compendium of Studies on Global Value Chains. Paris: Organization for Economic Cooperation and Development.

PWC. 2009. Automotive Review. Global Automotive Review. London: PWC Automotive Institute.

Rodrik, Dani. 2010. “The Return of Industrial Policy.” Project Syndicate. 12 April 2010. Accessed 22 September 2014. http://www.project-syndicate.org/commentary/the-returnof-industrial-policy.

Teng, Rachel. 2012. China's Auto Sector Development and Policies: Issues and Implications. Washington DC: Congressional Research Service.

United Nations Conference on Trade and Development. 2012. World Investment Report 2012: Towards a New Generation of Investment Policies. Geneva: UNCTAD.

United Nations Industrial Development Organization. 2011. Industrial Development Report. Vienna: UNIDO.

USTR. 2009. "USTR Report to Congress on China's WTO Compliance.” USTR News.

USTR. 2012. "Obama Administration Challenges China's Unfair Imposition of Duties on America-Made Automobiles.” USTR Press Release. 